\title{
MIRROR, MIRROR? : EXAMINING THE TRANSFORMATIVE NATURE OF POPULAR FAIRY TALES AS A REFLECTOR OF THE CHANGING WORLD
}

\author{
Azania Imtiaz Patel* \\ NMIMS, Jyoti Dalal School of Liberal Arts
}

\begin{abstract}
This paper suggests that the transformative nature of fairy tales is rooted in them serving as "mirrors" or reflectors of changes in the ideals held by the general populace, variance in norms or a change in acceptability of certain behaviors. It also seeks to observe the use of these stories as "tools" to encourage the acceptability of specific behaviors that deviate from norms previously held such as an increase in female agency, acceptability of homosexuality, and a defiance of the "damsel in distress" trope, or rather the "Prince as Savior" trope in contemporary times. It compares versions of popular fairy tales, with "Sleeping Beauty" as a key example, across media, both textual and audio visual. This paper attempts to identify the varying elements in these retellings across four broad timelines, categorized in this paper as (a) Pre-Grimm, (b) The Grimm Revolution (c) The "Disneyfication" and (d) Rejection/ Reconstruction and see how they correlate to changing ideals and views in the world they are incubated in and thus supposedly "reflect" or "mirror".
\end{abstract}

Keywords: fairy tales, reflector, retellings, feminism, Disney, Brothers Grimm

\section{Introduction}

The fairy tale is a curious genre, the fact that it has retellings is not a distinctive feature, rather it is distinct because it is a genre of retellings and adaptions, of tweaks and turns. It is a genre beyond stagnancy and one whose ownership is claimed by all. There is no one true "creator" of the fairy tale, and thus no "owner" of its narrative. Even when one speaks of the famed Brothers Grimm, they are collectors not owners. Even at the peak of capitalism, Disney's fairy tales belong to the audience. "The Happiest Place In The World"- Disneyland also functions on people claiming these fairy tale adventures for their own.

Zipes, in his work "The Meaning of Fairytale within the Evolution of Culture" draws a parallel between the genre and a whale that swallows all the small fish around it (standing in for various art forms and cultural institutions), and constantly adapts to survive. It is a beautiful metaphor, explaining quite aptly the evolution of the fairy tale itself as it changes itself to remain not just prevalent, but also relevant. In the very same work he elaborates on the difficulty to pin down a definition of the genre because of its "volatile and fluid nature". (2011)

But is the genre really fluid? To state that it is fluid would go beyond just the nature of its movement, it would also be to imply that it "takes the shape" of the container - the environment it is incubated in -holding it,. It would also be to imply that it has no distinctive shape of its own and would spill all over without being "cupped" or held. The fairy tale has indeed moved, and is impacted by its surroundings, which perhaps is what makes its retellings so profound as a subject of study. I would rather suggest that the tale is malleable, and perhaps more so than malleable, it is reflective. One could see it as a mirror, with fast moving wheels, revolving side by side with world, showing the viewer an image that is cast upon it. The nature of this mirror is what this paper hopes to understand and elucidate upon. The idea is to explore this nature through the example of a popular fairy tale, replete with numerous retellings across various periods of time, using a broad timeline as a tool to guide this process. The fairytale in this context is the "Sleeping Beauty" type story, classified by the Aarne Thompson Uther Classification as ATU 410 
At the very surface of the matter itself, other than the "reflective" aspect of this work, one would wonder why it should be titled "Mirror, Mirror" a quote best known for the tale "Snow White" when it is rooted in the "Sleeping Beauty" tale. It is so because the "mirror" the paper uses as an allegory to the genre is no ordinary reflective surface. It is, in fact much like the mirror from the "Snow White" tale. Mirrors and Looking Glasses have a long history of association with magic and witchcraft. They have been perceived as tools of the seer to look into the future, and to see beyond their own line of vision. The "mirror" that is the fairytale reflects an "ideal", it serves as a tool to see what the world should be, rather than just what it is. By no means can the fairy tale be called a "realistic" genre, but it is rooted in reality. Over the course of times it has been used to express models of behavior, dominant thought processes and even dissent. The fairy tale has been far more than just "nurseries of fancy" as Charles Dickens put them as (1853). Nor have their retellings been "tamperings" as he also claimed.

It is to expound this narrative of the fairytale as serving a reflective purpose that the paper looks at the various retellings of the "Sleeping Beauty" tale. To ask why this tale out of the many others is a valid question. It is because this tale type forms an interesting case study as it traverses not just time zones, but also geographic ones and has a distinct, largely traceable history in the written tradition. It has also become the subject of scorn in contemporary times due to its themes being called out as rooted in misogyny and being emblematic of the lager cultural influences adding upon to the phenomenon of "rape culture".

The most prominent theme of the tale, at least in the context of this work is that of the "evolution of the kiss". To look at the reflective nature of the story, this paper will take into account the various depictions of what has become know as the "Kiss of True Love" a trope that has also found itself widely accepted even outside the realms of the fairy tale. To delve into this more efficiently, the journey of "Sleeping Beauty" has been divided into four broad time lines, (a) Pre-Grimm, (b) The Grimm Revolution (c) Disneyfication and (d) Rejection/Reconstruction. These timelines are largely indicative and by no means comprehensive. They only serve as markers to see the projection of the culture upon the "fairy tale" in context to the ATU 410 and the scope of this paper.

\section{Pre-Grimm}

This timeline attempts to club together the prominent tellings of the Sleeping Beauty Type before the Brothers Grimm version of "Little Briar Rose". This is perhaps where the "origins" of the story can be traced back to.

The earliest forms of the tale type can be found in the medieval courtly romance "Pereceforest" and the Caltan novel "Frayre de Joy et Sor de Plaser". (Hasse, 2008). While neither work is classified as or called a "fairy tale", both of them have elements of a young girl falling into an enchanted sleep and being impregnated by a young man in the state of unconsciousness. It is quite evident that they have exerted influence upon the versions of the "fairy tale" by Baisle and Perrault, and those consequently on nearly all tellings and retellings of the story.

Pereceforest is not limited in its narrative to the "Sleeping Beauty" Type Tale. It embraces the themes of military gallantry and the "order of chivalry" one observes a direct dialectic relationship between the tale, and its assumed time period of 1330-1344, placing its creation in the midst of the Hundred Years War. The period has been termed as the "peak of chivalry". Thus the emphasis on the factor is not surprising in the tale.

Giambatissta Baisle's "Sole, Luna et Talia", translated as "Sun, Moon and Talia" heralds the literary fairy tale of the 17th Century. It is largely referred to as the "original Sleeping Beauty" in pop culture, and brings in the element of the "female rival", that largely morphs or is discarded in post the intervention of the Brothers Grimm. There are no fairies or goddesses in this tale, rather it is astrologers who warn a rich man of the danger his daughter faces from a distaff. 
The tale "reflected" the world Baisle lived in, one of aristocracy and political intrigue. However, it gave it a prettier look, a more idealistic one of justice, magic and heroes, the kind of reprieve that the people of the time perhaps needed, with the shockingly sparse economic conditions of the time period.

The fairy tale had become a resort for people to "fill the void that bourgeois realism left behind" and was seen as the only way to access the life of privilege (Canepa, 1999).

The "morals" of Baisle's 17th century society differed greatly from that of our 21 st century or in fact even from Perrault's France or the Germany that the Brothers Grimm resided in. The sexuality of the tale and the recurrent theme of the forbidden desire (more on that later) expressed through the King's rape of Talia did not raise the eyebrows then as it does today. The passivity of the "Sleeping Beauty" in a sexual encounter was the norm, and her maturation as a woman conscious comes only through the realization of her motherhood.

Perrault's story discards the overt sexuality of the story, and the "Sleeping Beauty" wakes up when the King nears her even without any sort of touch. The tale brings back the elements of the godmothers that Baisle had made do without from the idea of the Greek Goddesses and their blessings in Pereceforest. The rival to Perrault's Sleeping Beauty is not a jealous first wife, but an ogress for a mother-in-law. Where Baisle's first wife attempts to have Sleeping Beauty's children baked into a pie to be fed to their own father, the ogress desires to eat the children and the woman herself.

This element of cannibalism can be seen as symbolic of the forbidden appetite (Fay, 2008). From another perspective, the desire of the uninvited fairy to dine can be seen as a more figurative metaphor for the forbidden appetite. This translates into loss and doom, and in certain contexts demonization for the women.

In another tale by Baisle "Petrosinella", identifiable with the "Rapunzel" tale, the mother loses her child to an ogress (a witch in latter versions by Brothers Grimm and others) due to her cravings for the parsley from her gardens. The ogress too, suffers for seeking a child that is not her own.

A trend can be observed, of the women's ambitions as "unholy" and "forbidden" portrayed symbolically in monstrous ways and they largely lead to suffering. The fairy tale has been oft seen as a tool for socialization (Zipes, 2006) and these tales do reflect the "ideal" passivity of womanhood. There is the recurrent theme of the "bold, wicked woman" to be punished, and the "passive princess" to be rewarded. The "Sleeping Beauties" of Basile and Perrault live in a man's world and thus their liberation is at the hands of men too. This makes the argument of "consent" at least in the case of Baisle's story a nonissue as far at his time is concerned.

With regard to the gender and social hierarchies, these stories are direct reflections of their time. Both Baisle's and Perrault's world's are patriarchal and aristocratic. However, their stories don't just speak to the classes they "represent". They reflect an "ideal" to aspire for, giving a glimpse into the lives "good" people deserved, as long as they did not step out of line. It was a world of fairness and justice that the audience of these stories wished to see, and that is what they showed as mirrors and it was not unconscious, the shaping of these stories to shape young people's and often adults' behavior was born of a constructed effort to do so. (Zipes, 2006)

To speak of the evolution, or birth, in this case of the "True Love's Kiss" is interesting. While Baisle's "Sleeping Beauty" is impregnated in her sleep, Perrault's maiden rouses from her slumber at the proximity of her suitor. One can observe an increased value on the sanctity of marriage and marital bonds in this case. Between Baisle and Perrault, the fairy tale had also made a turn towards becoming "Children's Literature" and thus the suitability of the content can also be seen as a factor towards this. The change shows a negation in the sexuality, making it perhaps more "refined" and more tasteful, fitting in better with the thoughts and morals that Perrault wished to inculcate in his readers. 


\section{Grimm Revolution}

The Brothers Grimm are the most "popular" names when it comes to the layman's idea of the fairy tale, perhaps closely sharing that title with Disney. However, they were not the authors of these tales, they were collectors and editors. With their editing, came the "sanitization" of the story.

The Brothers were devoted collectors of the tale, in the preface to their third edition of their famed collection; they even expressed a desire that more of such tales be collected in the future. The Germanic tradition then saw the glorious past as a distraction from the distressing present, a recurring theme in hotbeds of retellings, and the Brothers wanted to retrieve the gold of the "oral tradition" (Michaelis-Jena, 1971).

Post 1970's the myth that the Bothers made very few changes to the tales they collected from the peasantry have been debunked. Rather they made elaborate additions, nixed out complete tales and expanded on the stories they had collected from the educated middle class and the petit bourgeoisie (Zipes, 2006).

A number of stories that are found in the first edition of their "Nursery and Household Tales" do not reappear in the latter editions because they have roots other than Germanic ones. It is curious that "Little Briar Rose" their retelling of "Sleeping Beauty" was retained throughout despite its explicit Italian and French roots. This was because instead of seeing it as a tale "borrowed" they saw it as a tale returned, claiming it originated in the Norse legend of the Valkyrie "Brunhild".

The movement of the Brothers Grimm in itself reflects the mood during their time to look back upon a "glorious" past and to recollect the virtues of an era gone by. The "ideal" was not in the present, it was in history and tradition. As Zipes observes, the "sanitization" of these stories that the Brothers Grimm collected had already begun at the hands to those they heard these tales from.

Of the numerous changes, a prominent one is how the elements of Baislie's sexually charged tale don't make any appearance in the story and it ends with the Prince, unlike the Kings in the previous tales, waking her up with a kiss and marrying her. It is indeed the Brothers Grimm version that brings in the "True Love's Kiss" far more chaste than Baisle's "distasteful" rape and yet more romantic than Perrault's version. The Brothers Grimm embellished the tale with more magic, and more grandeur and yet they aligned it with Christian and puritanical views. While in other works the waking up of the "Sleeping Beauty" is a part of the story, the Brothers Grimm made it the story. While the Brothers Grimm added magic and romance to the story, they eliminated the "corruption" in it. This allows one to observe how the idea that fairytales have a certain "purity" that needs to be maintained became the norm.

The tale they told is more straightforward, the Princess is rewarded for her feminine charms and suffering with an ideal match. He is rewarded for his bravery with a beautiful bride. The whole story then functions on prophecies and premonitions, from its beginning, with a mystical crab telling the Queen she will have a child to the curse being "softened" by the twelfth fairy, and its conclusion with a "happy ending," a wedding with the blessings of both the families. The shift in the conflict demonstrates a shift in the idea that the story propagates as well. The inclusion of a vengeful first wife would make the Prince less than adequate to be an ideal suitor with the Christian view on monogamy prevalent then. The mother as an ogress, as seen in Perrault's work would conflict with the Grimms' view on motherhood as sacred; a factor that influenced their latter revisions of other works as well.

This removal of the perceived "corruption" from these tales can be seen as a landmark of the works of Brothers Grimm. However, even across the six editions, one does not see tremendous changes in their retelling of the "Sleeping Beauty" tale, "Little Briar Rose." More explicit examples of their own literary trajectory, with Wilhelm Grimm stepping in as editor can be seen in the equally popular tales of Rapunzel and Snow White 
among other works. The motifs of Rapunzel becoming pregnant in the tower and Snow White's adversary being her biological mother and not her step mother were among key changes.

The Brothers Grimm reflected in their tales the roles and thoughts that the people wished to seek. Like with Perrault they saw themselves as "educators", to bring "refinement" to these tales and make them more eloquent and suitable was a task they relished. Their time and training was one that had emphasized on the splendor of the Germanic tradition. Their works in this field too was one to revive that tradition and to widen its reach. While their retellings and changes, especially ones across varied editions of their "Nursery and Household Tales" reflect the moral standpoint they held on to, the very essence of their "mission" is far more telling of the fervor towards protecting their Germanic heritage and giving a certain "tangibility" to it.

The Brothers Grimm may have contributed to giving fairy tales a pedestal, but it was Disney that solidified it. If the Brothers Grimm can be seen as the bourgeois missionaries using fairy tales for capitalist socialization, Disney made it a resource for their capitalist empire. From their 1937 making of "Snow White" followed by "Cinderella", the film that helped them gain back financial high ground post the Second World War, to the contemporary resurgence of Disney fairy tale films as "live action remakes", the corporation has a long history with fairy tales too.

\section{Disney fication}

Disney's "Sleeping Beauty" premiered in 1959, as a sure shot bet after the register ringers of "Snow White" and "Cinderella". However, it did not perform well at the box office and was the last fairy tale film in Walt Disney's lifetime. It was only after his death that it was followed up by "The Little Mermaid", thirty years later, in 1989.

Its lack of a resounding box office success does not decrease the impact that Disney left on the Sleeping Beauty legacy, and nor does it discount the fact that the film came in at very crucial juncture in time, when the United States was at the cusp of the Sexual Revolution of the 1960's, with rising incidents of premarital intercourse and children being born out of wedlock, and yet the disregard for "tradition" had not yet found itself in the "mainstream"

The cultural construction of women, especially white middle class women in the 1950's took them back to the domestic sphere, devoid of the moral seriousness of the nineteenth century (Burbick, 1996) while questions about a "woman's place" could be found in popular media too (Neauhaus, 1999).

Disney's "Sleeping Beauty" deals with these dilemmas too. The tale was based off both the Grimm and Perrault versions, with the Princess taking her name from Tchaikovsky's 1890 ballet based on the story as "Princess Aurora" and her alias "Briar Rose" from the Grimm tale. Despite a smidgen more of autonomy, if it can be called so, than the earlier princesses (she meets the Prince before she is kissed and does not sleep for a hundred years) Aurora still shines as the perfect "passive princess". Things are rarely done by her, and nearly always done to her. With barely eighteen dialogues in the feature length film, Disney's Aurora epitomizes the woman who is "seen but not heard".

This phenomenon of Disney's feminine tropes becomes more interesting when Aurora is juxtaposed to the other prominent women of the tale, namely the "good" Fairy Godmothers who look after her and the "wicked" Maleficent. These characters are in a sense autonomous and free of "male" dependence. In a context, they can be seen as powerful women, but their depiction makes matters more curious as it only seems to expound the "perfect princess" template for young girls. Maleficent and the Fairy Godmothers are intriguing characters, perhaps beloved even, yet they are not women to "look up" to. These women end up only on two extremes of the spectrum, one lonely and evil, and the other three as kind, bumbling fools in an almost spinster-isque way. The only idea woman is "Sleeping Beauty", who is obedient and innocent. In fact, her "true love" is also the man she was betrothed to as a child, exulting the virtues of parental choice. 
As Zipes says in "Fairy Tales and the Art of Subversion", Disney "domesticated" the fairy tale. By the end of the nineteenth century, fairy tales had become a staple of the children's diet, particularly with the advent of Hans Christian Anderson's tales that were in a sense more "church" friendly. (Zipes, 2006). Disney took this genre that was already being mass-produced and commodified it, selling virtue and tradition to the middle class family audiences.

In keeping up with the thought process, a desperate clinging of the "traditional" by the target audience of the film, the white, middle class family, there is a reinforcement of patriarchal norms throughout the film. The Princess suffers, literally for the sins of her father (a trope seen even more explicitly in the "empowering" Maleficent film of 2014), falls prey to her fate because of "bickering women", is trapped by the monstrous Maleficent, who literally transforms into a beast (one might see this as an allegory of an "untamed" or "undomesticated" woman) and is saved by a handsome Prince who also happens to be the man her parents chose for her to wed.

Princess Aurora becomes the ideal submissive virginal standard for femininity, a crime that tale is accused of in present time, and largely cannot be absolved of.

The question the debate around "Disneyfication" of fairy tales remains if by redacting the darker elements of the fairy tales, and negating some profound complexities and in the process making these stories once again accessible to the masses, were they made two-dimensional and in a way caricature-isque?

However, when one sees the context of the first phase of the "Disneyfication" one realizes why simple stories of glamour and romance would succeed in the post World Wars and mid-Cold War eras. The idea of "fairy tale justice" and thus the more dramatic climaxes, such as with Maleficent as a dragon being slayed in "Sleeping Beauty" propounded the "good always triumphs over evil" thought that the people in a sense desperately needed. The longing for a simpler world, and a prevalent romanticisation of the past was projected in these larger than life films with the damsel in distress as the charming prize of bravado and bravery, and the virtue of being "obedient" and "passive" as the path to success for the young female viewers.

While the 1959 "Sleeping Beauty" does take a moral high ground at least as far as the "kiss" is concerned, as it is not drawn out of lust (as in Basile) or attraction (as in Perrault or Grimm) but out of a genuine desire to save the Princess. In Disney's retelling, the Prince knows his kiss will wake his beloved; it is an act of "rescues" (despite its problematic legacy of highly uneven gender dynamics) thus in a sense saving it from being a subject of what can be called the "No Consent, No fairytale" conundrum, a theme elaborated upon later in this paper.

With the story coming to masses and fast growing out of just the United States with the onslaught of globalization and increasing communication, after its generation of "Disneyfied" or sugar coated retellings "Sleeping Beauty" has now found itself as being scrutinized, or rejected. The only way for it to survive in a world more aware of its misogynistic underpinnings is for it to be tweaked and made more "politically correct". To look at it from a more "capitalistic" view point, the tellers of these new stories, whether it be Sleeping Beauty or any other fairy tale for that matter, have realized that the new audience for their work is "woke" and thus the stories must be to. A shift in the "creator" or "adaptor" in the fairy tale has also been seen in the rather recent time as well, a shift that is best explored through the phenomenon of the Rejection and Restruction of the fairy tale.

\section{Rejection/Reconstruction}

While in the past years, the "fairy tale" has simply projected upon the people the popular thought and ideal, with the boom of social media, the pressure has be now put on this genre to "answer". The social media influx has led to the realization of the power of media over people, and inversely the power people hold over media. 
Social media thus has formed into a platform to give "voice" to the viewer, a phenomenon that has impacted the retellings of fairy tales to "mold" or adapt them into a form that is supposed to be truly reflective of thoughts and ideas fast gaining speed.

A prominent form of the "Reconstruction" of the tale is the feminist retelling. Carolina Fernandez Rodriguez, through a study of feminist retellings of "Sleeping Beauty" in comparison to the Baisle, Perrault and Grimm versions came up with four forms of how the "deconstruction of the male rescuer archetype takes place.

These include the "Demythologization of the Male Rescuer", a phenomenon one sees most distinctly in the "rejection" of this tale and retellings that emphasize on the "irredeemable" of the story. The other three forms work on "alternatives to the male rescuer" which include the "female rescuer", "Self Liberation" and "Homosexual Relationships as liberating forces". (Rodriguez, 2002). While these forms were developed in regards to literary works of the late twentieth century, one can see the relevance of these in more contemporary works as well, especially in the context of the "reflective" nature of these retellings.

While one will look at the "demythologization" lastly, in regards to the "rejection" of the tale, one can perhaps begin with looking at the reflective nature of a prominent retelling with the "female rescuer" substitution trope, namely the 2014 film "Maleficent". The film went from being praised initially until critiques of it emerged.

When one is to look at the 2014 Maleficent, in attempt to correct the wrongs of the past retellings that put women into three boxes of the beast, the fool and the passive angel, especially that of the 1959 predecessor by the corporation, one realizes that it pigeon holes the men, making it seem that the dynamics of the tale cannot change without not just a reversal of roles, but an exchange of them.

To give Maleficent a motive for her vindictiveness, going far beyond the petty lack of an invitation, the tale villainizes Aurora's father, King Stefan. The other prominent male character is Diaval, where the raven from the 1959 tale becomes an enchanted character, who turns from man to bird at will. He functions as a tool for Maleficent, despite inklings of a friendship and a romantic fascination, his arc receives no attention, mirroring those of many female characters in the past. It takes away the heroics by Prince Philip, and gives them in bits to both Aurora and Maleficent.

However the film still reduces Maleficent to a "mother" beyond all, an oft used redemption arc, rooted in gender roles. Could one say that the tale reflects or answers any pertinent questions? Perhaps it does. The film does come at a crucial juncture in children's cinema, and shines a prominent example in stories where the Princess is not saved by a man, it marks the curve towards the tales where the princess is not saved by anybody, and sheds the eons of passivity attached to the character tropes. It is reflective of the need to see powerful female character detached from the "vamp" trope and despite its flaws, it does light the path to a more "progressive" fairy tale, if such a term could be used.

This sort of maternal or familial "rescue" finds itself in a number of "fairy tale" films, including the 2013 "Frozen" loosely inspired from Hans Christian Anderson's "The Snow Queen", however one can not necessarily call it a retelling.

The other form the alternative rescuer takes is through "Self Liberation" this can be perceived in the 2011 film "Sleeping Beauty", directed by Julia Leigh. This is largely "reflective" work despite not being "idealistic". Rather it forms a sort of a cautionary tale, with its protagonist, while being trapped by her circumstances, is far from passive. The consequences she faces are of her own actions and not that of anyone else. Even her unconsciousness is "choice", and the means to an end. The film provides an integral contribution to the "consent" debate buzzing around the tale types with elements of enchanted sleeps and their consequent "waking". It, in a sense attempts to answer the question about where the line between "rescue" and "lack of consent" is located. The end of the film culminates with the protagonist being brought back to conscious 
through CPR by the madam of the brothel she's been working with, highlighting the distinct difference between the "lust" based actions in Baisle's tale and the "intentioned" actions of the Disney and other similarly put together consequent versions. Even though this film does not showcase a typical "happily ever after" ending, the protagonist's autonomous nature is largely typical of the collegian world it represents and takes place in.

When one looks at the idea of "Homosexual relationships as liberating forces" one must accept that the heteronormativity of fairy tales is an aspect of these stories which has been fast falling out of favor and while new stories have been written as "LGBTQ+ friendly" fairy tales, targeted especially to children, there is a growing demand for representation in popular stories that most people have grown up with.

An addressal of this, albeit almost negligibly with Lefou being shown as an "openly gay man" in the 2016 live action remake of Beauty and the Beast.

Another form of this has been the hashtag "give Elsa a girlfriend" as a vocal demand to give the much loved Ice Queen a lesbian story arc in the sequel, how this is to pan out is yet to be seen. Once Upon A Time included an episode dedicated to Red Riding Hood saving Dorothy (of Wizard of Oz) with True Love's kiss making waves with the sequence being far from fleeting as previously seen.

However, these kind of narratives are far from simple or bereft of complexities. They have often been called out as "fan service" or corporate marketing strategies. In fact, the LeFou sequence in Beauty and the Beast was called out for being a "much ado about nothing" with Disney publicizing it in excess, perhaps with an aim of milking favor from the LGBTQ+ community and in fact, it was even edited from versions playing at certain cinemas due to widespread protests by "conservative" parents. This response brings into questions of this supposed "move for non-discrimination" when put in the face of boycotts.

When one moves away simply from the "feminist retellings", one sees that this hope for being represented, and perhaps "empowered" in these narratives is not just a part of women's movements. The mobilization of "ignored" sections of the society "asks" to be included in these narratives.

However, the demand for representation or tweaks in tales to fit what is, perhaps ironically in this context, called the "woke" narrative, largely negates the complex, and at times problematic history of these stories and more so of the corporations expected to do justice to the "modern fairy tale". For instance, when one calls out Disney for casting a non-middle eastern actress as Jasmine in the live action remake of Jasmine or for creating a role for a white male actor that did not exist in the original, there is a sense of negation of the legacy of the tale which in a sense was the exoticization and commodification of a foreign culture directed towards a predominantly white, American target audience.

This brings in changes, no doubt, in the representation of marginalized or minority populations, whether in regards to sexuality, culture or race, but it still remains superficial. The manner of this representation is either trivial or "assimilating", almost as if saying that homosexuality in characters can be normalized only by following the same narrative template that the "heteronormative fairy tale" conforms to. These causal retellings or representations, driven not by debate or specific movements but rather by a need to stay relevant, financially especially, birth a "gratification culture". Prior to the contemporary times, consumers of media did not have this kind of say the creative stages of the product they are to consume.

While one cannot discount completely the idea that the reconstruction of these stories is the need of the hour and how prominent their effect is on the audiences they are targeted to, one perhaps needs to be cautious of problematic this phenomenon can be, and what could be a way to ensure the representation of previously unrepresented or misrepresented groups in the fairy tale genre. 
More radical as compared to champions of the cause to "reconstruct" the fairy tale, a genre known for its malleability are those who completely reject it as a relic of the past and symbols of a gender role based, heteronormative and homogenous society that cannot and should not be allowed to propagate its narratives as ideal anymore.

An example of this is a retelling that is less of a story or tale, and more of an "awareness" video is Amnesty International Canada's 2018 "NO CONSENT = NO FAIRYTALE" video that is just over a minute long and embodies the accusatory side in the debate of fairytales promoting non-consensual sexual acts. It does look at the legacy of the tales including the "True Love's Kiss" which at least in the context of "Sleeping Beauty" is predated by and originates from a rape but manages to strip it of all its complexities making it into a clear cut, black and white argument which it isn't. This comes post demands, spearheaded by a mother in Britan to have Sleeping Beauty removed from school syllabuses. It puts out in a sense, the message that the tale has never been and can never be palatable with its burdensome legacy. It can also be called an example of the "Demythologization of the Male Rescuer" trope.

Diana Goldstein's 2009 photography series "Fallen Princesses" created waves for its absolute "demythologization" of not just the "Prince" but the very cornerstone of the modern fairy tale, the "Happily Ever After". Despite its problematic nature, leaving bitter tastes of islamophobia in regards to the "Jasmine" image and the fat shaming in the "Little Red Riding Hood" recreation, it reflects a certain disillusionment with the very idea of a perpetual "happy life" and the ideals for a good life pumped from the world into the fairy tales and then pumped back into the system, drawing an analogy of an oversimplified cardiovascular system.

These photographs make visible the contradiction between what Angela Carter called the "mythical woman" and the everyday problems of the "real woman" (Bacchilega, 2013)

These rejections of the fairy tale, ironically coming usually through another batch of retellings reflect the distinct demystification of the genre amongst groups. It has inverted the reflection as well, as the story does not reflect an ideal, but rather it reflects the "unideal" nature of the genre itself, thus also commenting on its influence upon the society. These rejections, both found on the World Wide Web initially represent not just the "rejection" aspect of the fairy tale, but also a shift in the medium of communication.

When these retellings function as the "magical mirror" telling one of the ideal or the unideal (or what is considered so), the contemporary looker in the mirror, the member of the audience has the ability to crossquestion. This makes the relationship between the mirror and the viewer dialectic. It has given the genre a distinctive form. With the rise of self-publishing and crowd sourced platforms, the fairy tale has gone back to the masses. From comics showing "Fairy tale Princesses as Plus sized women" to pictorial representations of the regal characters as tea cups, the genre has become more malleable and subject to individual interpretation than ever.

Perhaps one could infer and conclude a movement towards a more individualistic, yet gratification based society, that still holds dear collective representation, a rather contradictory face, is being reflected in these retellings, that too are replete with contradictions. Despite the history of change, the fairy tale is more malleable than ever now and despite the calls for its rejection, it does not seem to be going away anytime soon.

Conclusion

The "mirror" has been an object of mystery and perhaps even magic for humanity. It thus becomes an apt metaphor for the fairy tale in more ways than one could imagine. The reflective nature of the fairytale is a curious thing, and that is what makes it quite difficult to pin down. The "fairy tale" is not a perfect mirror, but it isn't an imperfect one either. It reflects what is projected upon it through a lens of idealization, caution and even romance if that is what is asked of it. Thus, what could be called distortions in a "pure reflection", become 
elements crucial to this reflected image. It has become a medium that is capable of critiquing itself, and thus when it is placed in a world that holds the "fairy tale" as a whole in disdain, it reflects this sentiment as well.

In a contemporary world, one must realize how the reflective nature of the fairy tale is paramount to its existence; it is what gives the genre a certain universality and relevance, even when one skips from timeline to timeline, with the shifting morals and ideals of the world. Despite the arguments that may perhaps now hold the fairy tale as a genre that is of a bygone era, the use of new retellings to propagate this narrative is telling of how the tale is not irrelevant.

These newer retellings reflect the influence of the consumer upon the media they wish to "consume" turning the creation process into one of dialogue. While one could problematize aspects of this dialogic relationship as well, it has added another dimension to the collective ownership of the fairytale and solidified it a never seen before way. Even if it is through retellings that propagate the rejection of the tale or even the genre, or through ones that call for its narratives to be reconstructed, the fairytale has held on to its reflective nature.

With its pronounced reflective nature, the fairytale is a distinctively dialectic genre, and its discussions with the world do not seem to be ending anytime soon.

\section{Acknowledgements}

I would like to thank Dr. George Jose, Associate Professor, NMIMS Jyoti Dalal School of Liberal Arts, for his constant aid and timely feedback through the course of this research and its articulation.

\section{References}

Hasse, D., 2008, The Greenwood Encylopedia of folktales and fairytales. (Westport, Connecticut: Greenwood Press.)

Canepa, N.L., 1999. From Court to Forest : Gimbattista Baiieli's Lo cunto de li cunti and the Birth of the Literary Fairy Tale. (Detroit, Michigan :Wayne State University Press)

Zipes, J., 2011, The Meaning of Fairytales within the Evolution of Culture. Marvels and Tales, 25(2), 221-243

Tartar, M., 2014. Sleeping Beauty as Verbal Icon and Seductive Story. Marvels and Tales, 28(1) 142-158

Fay C., 2008, Sleeping Beauty Must Die: The Plots of Charles Perrault's "La Belle au bois dormant". Marvels and Tales, 22(2), 259-276

Rodriguez, C. F., 2002. The Deconstruction of the Male Rescuer Archetype in Contemporary Feminist Revisions of Sleeping Beauty. Marvels and Tales, 16(1), 51-70

Zipes, J., 2006. Fairy Tales and the Art of Subversion (New York, NY: Taylor and Francis Group)

Bachilega, C., 2013. Fairy tales transformed? Twenty-first century adaptations and the politics of wonder (Detroit, Michigan: Wayne State University Press)

Dickens, C., 1853, Frauds on the Fairies Household Words 184 (1) 97-100

Michaelis-Jena, R., 1971, Oral Traditions and the Brothers Grimm. Folklore, 84(2), 265-275

Neuhaus, J.,1999, The Way to a Man's Heart: Gender Roles, Domestic Ideology and Cookbooks in the 1950s Journal of Social History, 32 (3) 529-555

Burbick, J., 1996, Romance, Rodeo Queens and the 1950s. Frontiers: A Journal for Women's Studies, 17 (3) 124-145 